\title{
Developing College Students' English Autonomous Learning through WeChat Public Platform
}

\author{
Huijun Fu, Huijian Wang \\ Baoding University, Baoding, China \\ Email: fuhuijun@bdu.edu.cn
}

How to cite this paper: Fu, H. J., \& Wang, H. J. (2020). Developing College Students' English Autonomous Learning through WeChat Public Platform. Creative Education, 11, 942-952.

https://doi.org/10.4236/ce.2020.116068

Received: April 10, 2020

Accepted: June 27, 2020

Published: June 30, 2020

Copyright $\odot 2020$ by author(s) and Scientific Research Publishing Inc. This work is licensed under the Creative Commons Attribution International License (CC BY 4.0).

http://creativecommons.org/licenses/by/4.0/

\begin{abstract}
In today's era of network development, WeChat public platform can be used as a tool to assist college English learning. How to develop college students' English autonomous learning through the platform is the focus of the study. The study employs quantitative and qualitative research design involving 102 non-English major sophomores of Baoding University. The data collected from questionnaires reveal the problems existing in the construction of the platform, English teaching model, students' English autonomous learning styles and the management of the platform, and then several improvement strategies are advocated in practical teaching. Finally, an interview is carried out to prove the effectiveness of those strategies. The study is expected to achieve the effective application of WeChat public platform, and foster students' English autonomous learning ability.
\end{abstract}

\section{Keywords}

Learner Autonomy, WeChat Public Platform, English Learning

\section{Introduction}

With the development of Internet technology and the popularization of smart phones, WeChat as social software has already been quite popular among college students. WeChat public platform is one subscribing service of WeChat. It can satisfy different needs of learners. So English educators should take the advantage of WeChat public platform, and deeply explore the effective combination of WeChat public platform with English education. Promoting English autonomous learning is a target of college English teaching. As an old Chinese proverb goes, "Give a man a fish and you feed him for a day; teach a man to fish and you 
feed him for a lifetime." So to teach students to grasp the autonomous learning ability is quite crucial. It can ensure the development of students' other abilities. According to Rodgers \& Freiberg (1994), when students are free to learn what they wish as they wish, the whole climate of the classroom is completely different. The teacher becomes a facilitator rather than a teacher and evaluator. The study centers on the current situation of students' English autonomous learning based on WeChat public platform. Through analyzing the problems, researchers will propose effective strategies. The study result can increase students' English learning interest and promote effective English learning. Finally, the lifelong English autonomous learning ability will be grasped and enhanced, which can also ensure the university's output quality of applied talents.

\section{Literature Review}

This chapter includes three parts. The researchers mainly analyze the present situation of WeChat public platform, consult materials about learner autonomy, and investigate previous related studies.

\subsection{WeChat Public Platform}

WeChat public platform is a comprehensive service platform of WeChat. Set up by Tencent in Jan. 2011, one of the most influential Internet companies in China as well as the world, WeChat has fully developed in the sending of voices, pictures, messages, videos, etc., thus achieving the instant sharing of multi-modal resources. WeChat software itself is free. According to iiMedia Research, in 2019 , there was about $73.7 \%$ of Chinese netizens choose to use WeChat, which ranks the first among all mobile social products in China. Tencent reported its quarterly results that by Dec., 2019, WeChat active users had amounted up to 11,648 million. With such a large number of users, the use of WeChat public platform is undoubtedly universal.

WeChat public platform has several use functions, such as automatic response, voting management, page templates, approval management, originality management, etc. These functions can meet the needs of editing and posting, as well as the needs for backstage management. Meanwhile, they can influence the producing, sending, receiving and feedback of college English teaching materials.

WeChat public platform has the following features: First, it is easy to operate. Users only need to register an account, and then they can edit their information. Second, it is rich in content and various in forms with text, video, audio, image and so on. Flexibly adopting the various forms will arouse readers' interest and be more easily accepted by them. Third, it is instant and pervasive in spread, so learners can easily obtain abundant learning resources. Fourth, it can get timely feedback such as likes, reviews, and questions.

Based on the above use functions and features of WeChat public platform, college English teachers can apply it to their teaching in order to satisfy students' 
English learning desire. Besides, students can study the contents from the platform autonomously so as to enlarge their storage of English knowledge. Therefore, WeChat public platform is a beneficial teaching device.

\subsection{Learner Autonomy}

Since 1950s, learner autonomy has become a part of the research on educational psychology. Lev Vygostsky school, operationalism, social cognition school, and information processing psychology all have mentioned autonomous learning. Since 1970s, some scholars have defined learner autonomy. Holec first introduced learner autonomy to foreign language teaching. He elaborated learner autonomy and relevant practices. In his opinion, autonomous learning is "the ability to take charge of one's own learning" (Holec, 1981). Learner autonomy is also defined as "a capacity for detachment, critical reflection, decision-making, and independent action" (Little, 1991). Nunan (1997) placed learner autonomy as a critical ability and he advocated that "learners are able to define their own goals and create their own learning opportunities". Benson (2001) held that learner autonomy is "the capacity to control one's own learning". These different expressions of the definition are actually having one thing in common, which is autonomy as a capacity for learners.

Besides, different scholars give their understandings of learner autonomy. According to Zimmerman (1989), learner autonomy is closely related to classroom environment and social environment. Littlewood (1996) advocated learners should be responsible for their own learning, including the ownership of certain teaching processes such as the objectives, methods and evaluations. Benson \& Voller (1997) highlighted that learner autonomy should consider the learning situations, learning skills, as well as learners' inborn capacity, responsibility and their right to determine the direction of learning. Benson (2001) considered learner autonomy from three interdependent dimensions, namely the control over learning behavior, learning psychology, and learning circumstances. Pang (2001) summarized learner autonomy from the following aspects: capable of learning, want to learn, get to learn, and stick to learn. Learner autonomy means that learners can set up their own learning objectives, learning contents, learning methods, learning time and have their own set of evaluation system (He, 2003). Learner autonomy includes attitude, capacity and environment (Shu, 2004).

In conclusion, learner autonomy can take different forms. It will surely transform the traditional teacher-centered teaching to student-centered learning, thus leading the whole English learning process voluntarily and actively. In English teaching practice, teachers should join the educational reform and help students develop the autonomous learning ability.

\subsection{Previous Related Studies}

There are nine related studies on CNKI. They have three main characteristics. 
First, studies focus on one area of English study, for example, the improvement of autonomous learning ability in the translation or lexical aspect through WeChat public platform. Second, studies focus on universal college English learners or certain group of English learners, such as learners majoring in art. Third, studies focus on the application of the mode of learner autonomy or the construction of the autonomous learning platform based on WeChat public platform. However, the related studies lack the support of data. So the study in this field still has a large space to explore.

\section{Research Methodology}

\subsection{Research Questions}

In view of the necessity of students' English autonomous learning through WeChat public platform and also the previous related studies, the study mainly focuses on the following two questions:

Question 1 is the status quo of the construction and use of WeChat public platform.

Question 2 is the status quo of English autonomous learning through WeChat public platform.

Surrounding the two questions, the study is carried out by adopting quantitative and qualitative research methods. It is hoped that the study can help students promote their English autonomous learning ability when they learn by WeChat public platform.

\subsection{Participants}

Altogether 102 sophomores from Baoding University joined the research. They major in Intellectual Property and are from two intact classes. In daily English study, the two classes are put together to learn the same content. Each class has 51 students. Among them, 17 students are male and 34 students are female. They are between the ages of 19 and 21. All the participants have learned English at least 7 years. From the second semester of their junior year, students have used the WeChat public platform "Starfish English" to learn, so they have gained some experience.

\subsection{Research Instruments}

The research instruments involve two parts. Part 1 is a questionnaire. Distributed to all the participants, the questionnaire was designed to use five-point Likert Scale, which has five different answers, namely "strongly disagree", "disagree", "uncertain", "agree" and "strongly agree". It aims to investigate college students' English autonomous learning when they obtain learning resources from WeChat public platform. By discovering some problems, researchers hope to provide corresponding improvements. Part 2 is an interview after some reforms. It was carried out with 34 participants, one third of all the participants. The interview aims to check whether the improvements are effective or not. If 
the improvements are effective, they will be applied widely.

\subsection{Data Collection and Analysis}

At the start of the first semester of their sophomore year, students of the two classes from Intellectual Property were required to finish a questionnaire on English autonomous learning through WeChat public platform. While at the end of the second semester of their sophomore year, 34 participants joined an interview. The researchers have analyzed the collected data of the questionnaire as well as that of the interview respectively.

1) The analysis of the questionnaire

Table 1 shows the result of the questionnaire.

Item 1 to Item 4 is about the construction of WeChat public platform. 16.67\% of participants (17 participants) held that the platform was monotony in forms.

Table 1. A Questionnaire on college students' english autonomous learning through WeChat public platform.

\begin{tabular}{|c|c|c|c|c|c|}
\hline Item & $\begin{array}{l}\text { Strongly } \\
\text { disagree } \\
\%(\mathrm{~N})\end{array}$ & $\begin{array}{c}\text { Disagree } \\
\%(\mathrm{~N})\end{array}$ & $\begin{array}{c}\text { Neutral } \\
\%(\mathrm{~N})\end{array}$ & $\begin{array}{l}\text { Agree } \\
\%(\mathrm{~N})\end{array}$ & $\begin{array}{l}\text { Strongly } \\
\text { agree } \\
\%(\mathrm{~N})\end{array}$ \\
\hline $\begin{array}{l}\text { 1) WeChat public platform is } \\
\text { monotony in forms. }\end{array}$ & $6.86(7)$ & $52.94(54)$ & $23.53(24)$ & $13.73(14)$ & $2.94(3)$ \\
\hline $\begin{array}{l}\text { 2) The contents of WeChat public } \\
\text { platform are simple and boring. }\end{array}$ & $12.75(13)$ & $50.98(52)$ & $11.76(12)$ & $22.55(23)$ & $1.96(2)$ \\
\hline $\begin{array}{l}\text { 3) I want to join the editing work } \\
\text { of WeChat public platform. }\end{array}$ & $4.9(5)$ & $25.49(26)$ & $34.31(35)$ & $29.41(30)$ & $5.88(6)$ \\
\hline $\begin{array}{l}\text { 4) I want to join the management } \\
\text { of WeChat public platform. }\end{array}$ & $3.92(4)$ & $30.39(31)$ & $26.47(27)$ & $31.37(32)$ & $7.84(8)$ \\
\hline $\begin{array}{l}\text { 5) I always listen to my teacher with } \\
\text { little time to learn autonomously. }\end{array}$ & $6.86(7)$ & $28.43(29)$ & $22.55(23)$ & $34.31(35)$ & $7.84(8)$ \\
\hline $\begin{array}{l}\text { 6) I lack consciousness of } \\
\text { autonomous learning. }\end{array}$ & $3.92(4)$ & $26.47(27)$ & $25.49(26)$ & $37.25(38)$ & $6.86(7)$ \\
\hline $\begin{array}{l}\text { 7) My motivation of study on the } \\
\text { platform is to pass English exams. }\end{array}$ & $6.86(7)$ & $39.22(40)$ & $23.53(24)$ & $23.53(24)$ & $6.86(7)$ \\
\hline $\begin{array}{l}\text { 8) I think my English is poor and } \\
\text { have no confidence in it. }\end{array}$ & $4.9(5)$ & $23.53(24)$ & $19.61(20)$ & $37.25(38)$ & $14.71(15)$ \\
\hline $\begin{array}{l}\text { 9) When I use WeChat public } \\
\text { platform to learn, I don't } \\
\text { read further. }\end{array}$ & $1.96(2)$ & $19.61(20)$ & $23.53(24)$ & $50(51)$ & $4.9(5)$ \\
\hline $\begin{array}{l}\text { 10) My classmates and I seldom } \\
\text { discuss the contents of WeChat } \\
\text { public platform. }\end{array}$ & $1.96(2)$ & $20.59(21)$ & $24.51(25)$ & $41.18(42)$ & $11.76(12)$ \\
\hline $\begin{array}{l}\text { 11) My teacher doesn't grasp my } \\
\text { study on WeChat public platform. }\end{array}$ & $9.8(10)$ & $41.18(42)$ & $27.45(28)$ & $17.65(18)$ & $3.92(4)$ \\
\hline $\begin{array}{l}\text { 12) The messages on the platform } \\
\text { cannot be replied promptly. }\end{array}$ & $2.94(3)$ & $10.78(11)$ & $33.33(34)$ & $41.18(42)$ & $11.76(12)$ \\
\hline
\end{tabular}


$24.51 \%$ of participants ( 25 participants) were not satisfied with the contents because it's simple and boring. Based on the data, it's clear that WeChat public platform will be improved in both forms and contents. 36 students chose to join the editing work of WeChat public platform, and 35 students held neutral attitude, so about $69.6 \%$ of participants are expected to join the editing work. About $65.68 \%$ of participants (67 participants) are likely to join the management of the platform. Therefore, they should be encouraged to participate in the construction of WeChat public platform.

Item 5 to Item 8 is the investigation of English teaching model. In Item 5, $42.15 \%$ of participants (43 participants) always listened to the teacher with little time to learn autonomously. It indicates that teacher-centered teaching model should be reformed. In Item 6, only 4 participants (3.92\%) chose "strongly disagree" for the statement "I lack consciousness of autonomous learning". At the same time, 27 participants $(26.47 \%)$ chose "disagree". It is an indication that a large proportion of participants need to raise their consciousness of autonomous learning. In Item 7, 30.39\% of participants (31 participants) regarded their motivation of English study as a way to pass exams. $23.53 \%$ of participants (24 participants) held neutral attitude. Probably they were uncertain about their motivation of study. In fact, this motivation of study goes against the cultivating orientation of talents, so it's undesirable. Item 8 shows that teachers should help students build confidence in their English study, because $51.96 \%$ of participants (53 participants) chose "no confidence". Based on the above data, learner-centered teaching model will be advocated.

Item 9 to Item 10 is about students' English autonomous learning styles. $21.57 \%$ of participants (22 participants) chose to read further while using Wechat public platform. However, a large proportion of students don't have the consciousness of inquiry learning. 52.94\% of participants (54 participants) seldom discussed the contents of WeChat public platform with their classmates. This indicates they have not developed the habit of cooperative learning.

Item 11 to Item 12 can help English teachers find deficiencies in the management of WeChat public platform. As to the statement in Item 11, 4 participants (3.92\%) chose "strongly agree" and 18 participants (17.65\%) chose "agree". At the same time, $27.45 \%$ of participants (28 participants) chose "neutral". Maybe they were not certain. This suggests that teachers may neglect the control of students' study on WeChat public platform. Besides, 54 participants (52.94\%) held that they could not get prompt replies from WeChat public platform. It's also worthy of attention.

The questionnaire has revealed several defects exposed on WeChat Public Platform, as well as some problems of College Students' English Autonomous Learning. English teachers are expected to make corresponding improvements, so as to effectively help students improve the quality and level of English autonomous learning.

2) The analysis of the interview

Table 2 shows the result of the interview. 
Table 2. An interview after improvement.

\begin{tabular}{lcc}
\hline \multicolumn{1}{c}{ Questions } & \multicolumn{2}{c}{ Feedbacks } \\
\cline { 2 - 3 } & Yes & No \\
\hline $\begin{array}{l}\text { 1) Is WeChat public platform improving? } \\
\begin{array}{l}\text { 2) Have you enhanced your English autonomous } \\
\text { learning? }\end{array}\end{array}$ & 34 & 0 \\
$\begin{array}{l}\text { 3) Do you inquire into the knowledge on our } \\
\text { WeChat public platform? }\end{array}$ & 32 & 2 \\
$\begin{array}{l}\text { 4) Are the monitoring level and the quality of } \\
\text { feedback improving? } \\
\text { 5) Do you have any other suggestions? }\end{array}$ & 34 & 0 \\
\hline
\end{tabular}

The interview consists of five questions. Question 1 shows that all the 34 participants admit the improvement of WeChat public platform. In Question 2, 31 participants agree that their English autonomous learning have enhanced. However, 3 participants disagree. That means the teacher should continue cultivating students' English autonomous learning. In Question 3, 32 participants can inquire into the knowledge on our WeChat public platform, while 2 participants have difficulty. So their ability of inquiry-based autonomous learning still needs to be cultivated. In Question 4, all participants are satisfied with the improvements on monitoring level and the quality of feedback. In Question 5, 3 participants give their suggestions. First, they suggest the release time of platform information should be regular, so that they can check the information in time. Second, they want to obtain more major-related contents from WeChat public platform. Third, they are also willing to give regular feedback on the platform. These precious suggestions have been accepted by researchers.

\section{Strategies to Promote College Students' English Autonomous Learning through WeChat Public Platform}

Based on the above analyses, there're several strategies to promote English learner autonomy through WeChat public platform. These strategies mainly focus on the optimization of WeChat public platform, teaching model, students' learning mode, and the monitoring and feedback mechanisms. It is hoped that these strategies can achieve the better application of WeChat public platform as well as the promotion of autonomous learning ability.

\subsection{Strengthening the Construction of WeChat Public Platform}

At present, the construction of WeChat public platform is still in the startup phase. In order to optimize English autonomous learning environment, the platform needs to be improved mainly in the following three aspects:

First, in terms of the form, WeChat public platform should be flexible and various. It should not only involve text information, but voices, images and videos. So the material database of the platform should get enlarged. With the in- 
crease of publishing, the contents are enriched. To help learners quickly find the information, the editor should classify the contents by adding some custom menus. Therefore, learners can get information conveniently. Besides, the editor can beautify the pages with the aid of the third-party editors, such as 135 Editor, XIUMI and so on. These editors can be applied to the layout design, thus making the pages more viewable. Besides, they can also raise the learners' interest.

Second, WeChat public platform should be rich and scientific in content. The content involves listening, speaking, reading, writing and translation, and aims to develop these basic English skills of college students. It should not be limited to English textbooks, but should be an extension of classroom learning. Meanwhile, originality is encouraged. From the platform, students can obtain many English learning resources such as songs, speeches, debates, word usage, cultural contrast, famous lectures, mini-lectures, study methods, tests, etc. Based on students' learning needs and interests, the content should also get close to their study, life and major. Some knowledge of ESP (English for Specific Purposes) can be introduced. Besides, the content should capture the trend of the times. While knowing about the news happened at home and abroad, students have their sense of responsibility and patriotism further developed.

Third, WeChat public platform should strengthen its management. In order to promote learner autonomy, students are encouraged to edit the English learning materials, and they are also welcomed to join the management of the platform. So the teacher can cooperate with students to set up an operation team of WeChat public platform. In order to ensure the quality of each release, the teacher should invite related professionals to give lectures and help the operation team familiarize the functions of the platform. Meanwhile, the operation team should set the release time of platform information according to students' work-rest schedule, and release regularly. By this way, more students can read the information effectively.

\subsection{Promoting Learner-Centered Teaching Model}

In order to better develop college students' English autonomous learning ability, teachers need to promote learner-centered teaching model.

On one hand, English teachers should change their traditional teaching roles. In traditional English class, teachers tend to teach from the beginning to the end. Students' participation is neglected, which causes their less interest in the class. To change this situation, teachers should transform into designers, guides, organizers and counsels of the whole English teaching process. They need to transfer certain powers to students by leading them actively participate in the classroom activities. Hence, learner-centered teaching model is emphasized, and effective teaching can be realized.

On the other hand, English teachers should cultivate students' consciousness of autonomous learning, which is quite crucial for learning English. At present, students are encouraged to obtain various English learning resources from We- 
Chat public platform. By means of it, teachers can lead students to develop correct study motivations, which should be taken into consideration at a higher level. The motivations of English study should not just be limited to passing the final exams or even some college English proficiency tests, but should be oriented to the cultivation of English ability and using English to better communicate with the world. Meanwhile, students' sense of self-efficacy should get promoted. Self-efficacy can reflect students' confidence in English learning tasks. By studying from WeChat public platform, students can gradually cultivate their self-efficacy, and then their self-confidence and interest are growing. Moreover, attribution of success and failure is also important. Based on different learning materials form WeChat public platform, students may encounter various difficulties. If teachers can guide students to correctly analyze the attribution, they'll improve English study more effectively.

\subsection{Cultivating Inquiry \& Collaboration-Based Learner Autonomy}

In the application of WeChat public platform, English teachers should promote inquiry and collaboration-based learner autonomy.

In English learning process, inquiry-based learner autonomy is advocated. First, college English learning should not be confined to the study of passages in English textbooks. Teachers can assign textbook-related topics to students, and let them to inquire into more knowledge. Then students can share their information on WeChat public platform. So WeChat public platform can provide a space for students to foster their initiatives and autonomous learning ability. Second, based on WeChat public platform, students are encouraged to inquire into a wider range of topics, which may involve their interest, major, short-term or long-term learning objectives, etc. Third, they are encouraged to think independently and take the responsibility of knowledge inquiry actively. After reading those materials, they need to analyze the materials, discover the important and difficult points, and pay attention to the main idea, English grammar and also language points. As to difficulties, they need to overcome by consulting other related books or seeking for advice from their English teachers. Next, they need to develop the ability to conclude information, and form viewpoints or attitudes, so as to autonomously construct their own knowledge structures and values.

In addition, collaboration-based learner autonomy should also be promoted. As to the publishing tasks of WeChat public platform, teachers should first discuss with students, and investigate their learning psychology, interests, experiences, English competence, and their needs of reading. After grasping their basic information, teachers can divide them into different groups. According to different topics assigned each week, students should cooperate with each other to find related materials. They can also join the editing work of WeChat public platform. Besides, for information from WeChat public platform, English teachers can raise questions in class, and then encourage students to have group dis- 
cussions and give answers mainly through interactions. If they encounter some problems, the teacher will give them necessary guidance. In this process, teachers attach more importance to students' English autonomous learning. Meanwhile, students' English knowledge and learning skills are promoted. Finally, students can use WeChat public platform to realize extensive exchanges after class. They can leave their messages, and obtain other people's opinions at the same time, which is helpful to solve their learning difficulties collaboratively. Hence, WeChat public platform is transformed into a collaboration-based autonomous learning environment.

\subsection{Perfecting the Monitoring and Feedback Mechanisms}

WeChat public platform should perfect the monitoring and feedback mechanisms. As to the monitoring aspect, WeChat public platform can be monitored in the background as it provides statistical function. Teachers can obtain a series of analyses, such as the analysis of users, contents, menus, messages, interfaces and pages. Among these analyses, numbers of students' reading and hitting of "likes" will be seen as reference for evaluating the content of WeChat public platform. Their reading tendency can also get monitored. At the same time, students are suggested to change their nicknames to real names. The participation rates can be considered into their usual-time performances. Therefore, students' reading enthusiasm gets promoted, which will surely enhance their autonomous learning ability.

WeChat public platform should also strengthen its feedback mechanism. First, after each push of pages, teachers should evaluate students' work by presenting the strengths and weaknesses, which can help them improve their English learning without discouraging them. Second, in English autonomous learning, students are encouraged to express their views or questions on the platform. As students are using their real names, teachers can give timely feedback to help them overcome difficulties and also give more targeted suggestions. Third, students should be required to give regular feedback on WeChat public platform, which include both the content and the form. So the feedback is a two-way interaction. It aims to effectively assist students' autonomous learning.

\section{Conclusion}

WeChat public platform is the product of information technology. With the development of times, it should be integrated into college students' English learning, because it can break the communication barrier between teachers and students, and build better communication channels. Besides, English autonomous learning is essential for the promotion of English proficiency. After the investigation into students' autonomous learning through WeChat public platform, the study reveals some problems. In order to better develop their English autonomous learning, the study provides four strategies, which includes the construction of WeChat public platform, teaching model, inquiry and collaboration-based 
learner autonomy, and the monitoring and feedback mechanisms. These four strategies have been proved to be effective in the study. So the study has both theoretical and practical significance.

It is hoped that the research result will be widely applied to English teaching and learning practice, thereby students' consciousness of English autonomous learning will get improved. Their learning initiative will be activated. Their English autonomous learning ability will get promoted, too. However, because of the miscellaneous feature of WeChat information, students are likely to get distracted. How to avoid this distraction deserves further study.

\section{Conflicts of Interest}

The authors declare no conflicts of interest regarding the publication of this paper.

\section{References}

Benson, P. (2001). Teaching and Researching Autonomy in Language Learning. Harlow: Longman.

Benson, P., \& Voller, P. (1997). Autonomy and Independence in Language Learning. London: Longman.

He, L. Z. (2003). Learner Autonomy and Ability Cultivation. Foreign Language Teaching and Research, No. 4, 17-19.

Holec, H. (1981). Autonomy and Foreign Language Learning. Oxford: Pergamon.

Little, D. (1991). Learner Autonomy: Definitions, Issues and Problems. Dublin: Authentik Language Learning Resources Limited.

Littlewood, W. (1996). Autonomy in Communication and Learning in the Asian Context. The Development of Learner Independence in Language Learning. Bangkok: King Mongkut's Institute of Technology Thonburi.

Nunan, D. (1997). Designing and Adapting Materials to Encourage Learner Autonomy. London: Longman.

Pang, W. G. (2001). On Students' Learner Autonomy. Journal of East China Normal University (Educational Sciences), 20, 78-83.

Shu, D. F. (2004). Foreign Language Teaching Reform: Problems and Strategies. Shanghai: Shanghai Foreign Language Education Press.

Zimmerman, B. J. (1989). A Social Cognitive View of Self-Regulated Academic Learning. Journal of Education Psychology, 81, 329-339.

https://doi.org/10.1037/0022-0663.81.3.329 